Research Article

Magdalena Apollo*, Agata Siemaszko, and Emilia Miszewska-Urbańska

\title{
The selected roof covering technologies in the aspect of their life cycle costs
}

https://doi.org/10.1515/eng-2018-0053

Received May 25, 2018; accepted Jul 19, 2018

Abstract: In the article is presented an analysis of the life cycle costs calculation for selected roof coverings. The scope of research includes costs of construction, maintenance and demolition of the roof covering structure for two alternative technologies - the traditional and new generation. On the presented example of an industrial building with a roof area of $1000 \mathrm{~m}^{2}$, the above costs are taken to consideration for the roof covering made of two thermoplastic asphalt torching polymer membrane layers and a new generation PVC thermoplastic film with a reinforcing layer. The input data presented in the article comes from the investor (the owner of the future facility) and from property managers responsible for the maintenance of facilities in regard to the purpose, volume and applied method.

The subject of the research is the analysis of the range of impact of the selected roof covering technology on the long-term costs of its maintenance. The aim of the research conducted by the authors is to indicate the possibility of reducing the costs related to the maintenance and elimination of a selected building structure (roof covering) in the assumed period of its operation for 70 years.

Keywords: LCC analysis, initial investment, maintenance and renovation costs, operation of the building, damage repair, lifetime of the building

\footnotetext{
*Corresponding Author: Magdalena Apollo: Faculty of Civil and Environmental Engineering, Gdansk University of Technology, Gdańsk, Poland; Email: magdalena.apollo@pg.edu.pl Agata Siemaszko: Faculty of Civil and Environmental Engineering, Gdansk University of Technology, Gdańsk, Poland;

Email: agata.siemaszko@pg.edu.pl

Emilia Miszewska-Urbańska: Faculty of Civil and Environmental Engineering, Gdansk University of Technology, Gdańsk, Poland; Email: emilia.miszewska-urbanska@pg.edu.pl
}

\section{Research problem}

Roofs and flat roofs of large surfaces, due to their design and shape (including small roof slopes), require special solutions of covering materials, hoods details and edge treatments. All these elements must ensure complete tightness and failure-free drainage of the roof surface. An important element that provides the above features is the material used to make the roof covering. There are many possibilities in this area. In practice, the roof covering is made of roofing membrane, foil, plastic (PVC), rubber membranes (EPDM), etc. In many cases, after considering several variants of the object's creation technology, the investor is faced with the need to make an investment decision. At this stage, he analyzes the advantages and disadvantages of various solutions such as their durability and reliability, but also economics. From the owner's and /or user's of the facility point of view, the cost of maintaining the roofing material in a proper technical and aesthetic condition is important. In any case, roof covering requires periodic maintenance and renovation. Its frequency mainly depends on the operating conditions $[1,2]$. The repair of coverings and roof flashings on a large roof surface in the facility being operated is often associated with numerous technological, logistical and organizational difficulties. Therefore, it is important to design and build the roof covering that it is reliable (durable and tight) for as long as possible (it is assumed that it will be up to 70 years) $[3,4]$.

From the perspective of the investor and/or user of the facility, it is important to compare the costs incurred at the stage of covering the costs generated during its maintenance [5]. The entire life cycle cost of a given roof covering includes the cost of its implementation (initial investment) and the costs of repairs, ongoing renovations (in a defined range), winter maintenance (snow removal), general renovations (full coverage) and elimination. 


\section{The life cycle cost}

According to $[1,7]$ the cost of a building's life cycle is the process of economic analysis covering the sum of costs of purchase, use, maintenance and demolition of a building. According to [6-8]:

- the purchase cost includes costs related to construction works being the subject of the order including the cost of equipment permanently associated with the building, the cost of design documentation for technical specifications and acceptance of construction works (Specifications for Construction Work Accomplishment and Acceptance) and service costs during the warranty period granted by the contractor,

- the cost of use includes costs related to the consumption of energy or energy carriers and water,

- costs of maintenance are related to the operation of the building and include mainly the costs of renovations, replacements, repairs and maintenance, which allows to maintain the building in a proper technical and aesthetic condition,

- the demolition costs are related to the liquidation of the facility and include demolition of the building, export, development, utilization and recycling of waste.

It should be emphasized that [6] project primarily refers to the life cycle costs of a building. The example presented in the article refers to the selected element of the object - roof covering. Therefore, the costs of use were omitted in the calculation of life cycle costs for the two analyzed variants. The costs of purchase, maintenance and demolition of roofing are included.

According to $[6,9]$ the costs of purchasing an element are presented in the offer submitted by the contractor.

According to [6] maintenance costs are calculated as the sum of unit maintenance costs of products during the calculation period, reduced by the value of the contractor's warranty for a given product, accordingly with formula (1).

$$
C_{u t}=\sum_{k=1}^{n}(A n-B n)
$$

where:

$C_{u t}$ - the cost of maintenance,

$A n$ - the cost of maintaining the $\mathrm{n}^{\text {th }}$ product in the calculation period,

$B n$ - the value of the contractor's warranty for the $\mathrm{n}^{\text {th }}$ product.

According to [6] the cost of maintaining the $\mathrm{n}^{\text {th }}$ product during the calculation period is determined by the for- mula (2).

$$
A_{n}=I \times K \times N
$$

where:

$I$ - the number of product units,

$K$ - the cost of replacing the unit of the product,

$N$ - the number of cycles of product use in the calculation period.

According to [6], the value of the contractor's warranty for the $\mathrm{n}^{\text {th }}$ product is calculated from formula (3).

$$
B_{n}=A_{n} \times \frac{O_{g}}{O}
$$

where:

$O_{g}$ - the contractor's warranty period expressed in years, $O$ - the calculation period.

It should be emphasized that in a broad approach, the LCC analysis provides an important data that is crucial in the process of designing, development, operation and the liquidation of object, a product, and a construction element $[10,11]$. Estimating life cycle costs can also be effectively applied to compare and assess the operating costs of an object construction element for alternative variants $[12,13]$.

Providers of various technologies and products can optimize their projects by assessing various alternative solutions $[14,15]$. At the stage of selecting an investment variant, the investor also has the opportunity to optimize its decision based on the calculation of the life cycle cost of an object or construction element and the analysis of various strategies for their use, maintenance and liquidation [16].

The cost of making and maintaining roofing, while maintaining its reliability condition depends on many factors. These include the scope of the technical design, the quality of the roofing's coverage, as well as the scope of works related to its maintenance [17].

Determining the amount of the investor's reasonable expenses, in terms of the life cycle cost of roof covering, requires the definition and consideration of the above issues at the stage of preparing the project documentation. In practice, in many cases, investors analyze only the initial capital expenditure [18-21], omitting the long-term expenditure on the operation of the roof covering material [22, 23].

\section{The analysis of the life cycle cost for two variants of roof coverings}

In the article are taken in to consideration two technologies for roof covering: 
- made from two layers of asphalt polymer-weldable roofing membrane,

- made from a new generation PVC thermoplastic film with a reinforcing layer.

The LCC analysis is carried out accordingly to the methodology contained in [6]. For the purposes of the analysis was defined the time horizon - 70 years were adopted, and then the cost components were determined. The analyzed costs were established based on the knowledge of experts: the investor (the owner of the future facility), property managers responsible for the maintenance of facilities of similar nature and current price publications. According to [24], 70 years occupation time has been adopted (category of performance period: $4 / 5$, designed performance period: 50/100 years). The assumed occupation time was also adopted based on the knowledge of experts - property managers, based on the assessment of the technical deterioration degree of the building made with the use of the Ross method taking into account the scope and frequency of renovations and maintenance of the facility. The discount rate was based on the current NBP information.

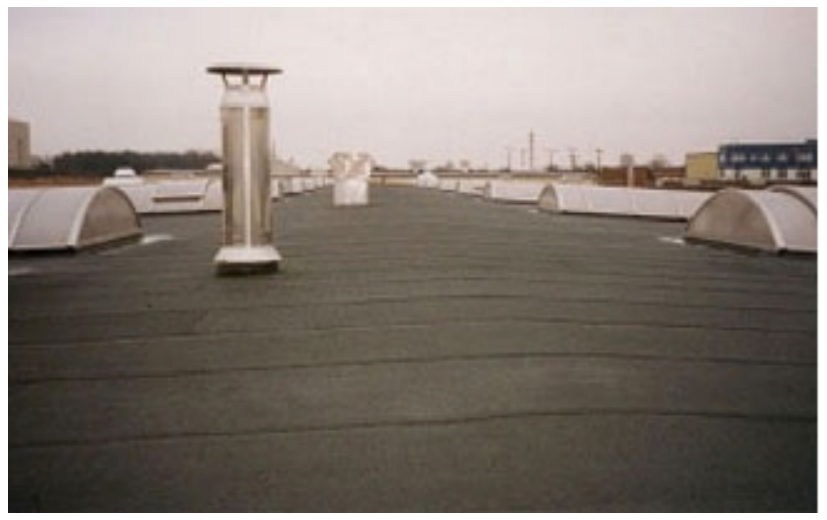

Figure 1: The view of the roof area with an area of $1000 \mathrm{~m}^{2}$ selected for conducting this analysis.

In order to carry out the cost analysis, the following assumptions were made:

- the calculation of roof covering costs was made for a roof with an area of $1000 \mathrm{~m}^{2}$ (Figure 1),

- a 70-year calculation period has been adopted,

- for initial costs (purchase costs) only works related to the roof covering - without the insulation layers mounted on the roof structure panel and without flashings, gutters and downpipes were taken into consideration,
- the initial investment (purchase cost) includes the purchase cost of all materials necessary to make the roof covering and the costs related to their transport to the building site,

- average unit prices were determined based on the information contained in the price publication [25], information obtained from the market and individual calculations,

- a discount rate of $1.75 \%$ was adopted.

Based on the experience of managers responsible for maintaining facilities of a similar nature, the following strategy for maintaining roof covering was adopted:

1. with two layers of asphalt polymer-weldable roofing membrane:

- winter maintenance - snow removal will be carried out twice a season,

- periodic renovations will be carried out every 5 years on $10 \%$ of the roof surface; the assumed number of renovations: 13 ,

- general repairs will be carried out every 30 years on $100 \%$ of the roof surface; a number of renovations: 2 ,

- waste utilization and disposal: every 5 years - material removed from 10\% roof area (13 times) and every 30 years - material removed from $100 \%$ of roof area (2 times).

2. with a new generation PVC thermoplastic film with a reinforcing layer:

- winter maintenance - snow removal will be carried out twice a season,

- periodic renovations will be carried out every 10 years on $10 \%$ of the roof surface; a number of renovations: 6 ,

- general repairs will be carried out every 40 years on $100 \%$ of the roof surface; number of renovations: 1 ,

- waste utilization and disposal: every 10 years material removed from $10 \%$ roof area ( 6 times) and every 40 years - material removed from $100 \%$ of roof area (once).

In both cases, the maintenance costs of the roof covering were reduced by the value of the warranty granted by the contractor to perform a new covering on the entire roof surface. The value of works performed by the contractor during the 5-year period (the warranty period granted by the contractor) was set as $5 \%$ of the value of the initial covering implementation. 
Table 1: Components of life cycle costs for two alternative technologies of production, maintenance in the period of 70 years and elimination of roof covering.

\begin{tabular}{lcccccc}
\hline Type of roof covering & $\begin{array}{c}\text { Initial } \\
\text { expenditure }\end{array}$ & $\begin{array}{c}\text { Current } \\
\text { maintenance }\end{array}$ & $\begin{array}{c}\text { Current } \\
\text { repairs } \\
{\left[\text { PLN/1000 m }{ }^{2}\right]}\end{array}$ & $\begin{array}{c}\text { General } \\
\text { repairs }\end{array}$ & $\begin{array}{c}\text { Utilization } \\
\text { of waste }\end{array}$ & LCC \\
\hline $\begin{array}{l}\text { Coverage of two layers of thermo- } \\
\text { weldable asphalt polymer roofing } \\
\text { membrane }\end{array}$ & 29854,78 & 78387,9 & 24657,98 & 92541,07 & 10480,7 & 235922,4 \\
$\begin{array}{l}\text { Cover made of a new generation } \\
\text { PVC thermoplastic film with a rein- } \\
\text { forcing layer }\end{array}$ & 41750,21 & 78387,9 & 16854,21 & 67231,76 & 4231,76 & 208455,8 \\
\hline
\end{tabular}

According to the assumption adopted at the design stage, both proposed variants of roof covering should meet the leak tightness requirements for a period of 30 years (for roof membrane covering) and 40 years (for foil covering), and the roof structure should ensure safe operating conditions of the facility by the facility assumed lifetime, i.e. 70 years.

The reparation of old layers of roof covering membrane consists of repairing existing damages, such as loosening, blisters, folds, lumps, cracks, etc. Separation and blisters should be cut, inverted and dried, and then welded or glued with an asphalt stick. Folds and bulges should be felled and leveled. With extensive damage, it is advisable to cut them down to the ground, and then patches should be pasted with a new roofing membrane.

In the event of moisture found under the old cover, which is the case for most repaired roofs, it is recommended to make an insulation system composed of perforated roofing membrane and ventilation chimneys in the amount of 1 chimney on the $40-60 \mathrm{~m}^{2}$ of the roof.

In order to enable effective moisture removal, the surface of the old roofing membrane should be unsealed up to the moist layer, for example by making holes with a drill or cutting the old substrate.

After calculations based on formulas (1), (2), (3), individual components of life cycle costs were calculated for the technologies of roof covering and are summarized in Table 1.

A graphical comparison of initial expenditure, maintenance costs over 70 years, liquidation and total LCC values for two roof covering technologies is presented in Figure 2.

It should be emphasized that the comparison of initial expenditure with the costs generated during the roof covering exploitation period (Figure 3) gives the investor a full picture of the actual expenses that he will be forced to incur during the assumed lifetime of the facility (and cov-

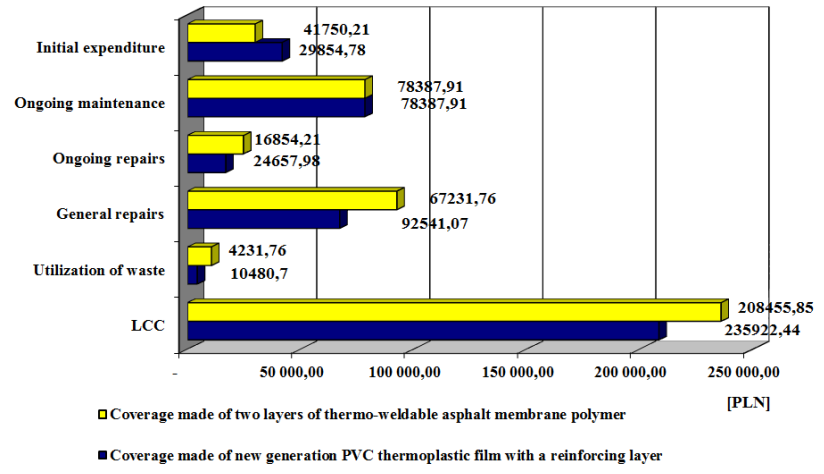

Figure 2: LCC analysis for two variants of roofing (source: own study).

erage). These expenses are a result of carrying out repair works for the roof covering at specified intervals, but also redoing the roof structure protection in full range - accordingly to the manufacturer's instructions for the given type of covering.

In the light of the above analysis, it can be concluded that taking into account only the initial investment, the more expensive variant is the implementation of a new generation PVC thermoplastic film with a reinforcing layer. The cost of making the cover made of two layers of asphalt polymer-welded roof membrane accounts for $12.65 \%$ of the total life cycle costs.

The cost of making PVC covering consists of $20.03 \%$ of the life cycle cost (Figure 3). It is anticipated that activities related to the ongoing maintenance of roof covering for both variants (including winter snow removal) are associated with spending the same amount by the invertor. Significant differences can be seen in relation to the costs associated with maintaining the roof covering in the long term. Taking into account the discounted costs of maintaining the roof covering in the assumed period of 70 years, including general and ongoing repairs, the more expensive solution is coating with thermo-weldable roof- 
ing membrane. Faster aging time of this covering, the loss of flexibility and resistance to weather conditions cause a significant reduction in its durability in the analyzed period. In practice, this means that every 30 years the labor-intensive and costly replacement process must be repeated. The use of roof membrane, in the course of operation also means more frequent undertaking of costly activities related to ongoing repairs.

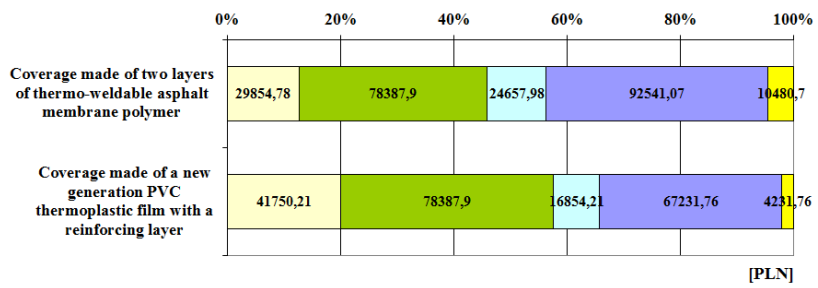

$\square$ Initial expenditure $\square$ Ongoing maintenance $\square$ Ongoing repairs $\square$ General repairs $\square$ Utilization of waste

Figure 3: Percentage of individual components in the life cycle costs of roof covering for two variants.

source: own study

Taking into account the total life cycle cost, i.e. initial investment, 70-year maintenance and disposal period for two analyzed variants, it can be concluded that the cheaper solution is a new generation PVC thermoplastic film with a reinforcing layer. In the long-term, it generates lower expenses incurred by the owner and/or user of the facility.

\section{Conclusions}

The conducted analysis and own authors experience justifies the formulation of the following conclusions and recommendations.

1. In the article is indicated the possibility of using a new approach based on estimating life cycle costs in the process of choosing the technology of roof covering material implementation. It allows to indicate the investor the optimal variant, which with reduced roof maintenance costs (resulting from limiting the scope and frequency of renovation work), ensures that certain safety, quality and aesthetics standards are maintained. Therefore, it is possible to significantly reduce the costs incurred by the investor during the operation period of the facility.

2. The presented analysis confirms the long-term financial benefits for the investor and/or the user of the facility, resulting from the application of a cover made of a new generation PVC thermoplastic film with a reinforcing layer. It also justifies applying in practice mainly in the process of designing a new cover or replacing an existing one, which results from the LCC analysis. It allows to indicate the optimal solution in terms of the total life cycle cost, taking into account initial costs and costs incurred in the course of maintenance and liquidation of a given element or the entire facility (considered in the longterm).

3. In any case, regardless of the applied type of roofing technology, apart from the financial aspects taken into account by the investor, the cover must meet all the requirements. It should be therefore characterized by adequate resistance to external environment impacts, proper mechanical resistance and full tightness of all joint connections as well as other accompanying elements (flashings, etc.). This means that the construction and use of the roof covering as well as flat roofing must be fully adequate with the manufacturer's instructions. In the above context, the LCC analysis assumes the option of choosing a variant with a lower life cycle cost, but assuming the proper use of the covering (savings can not be the result of negligence in works related to maintaining the covering).

4. Experience from the practice indicates that the LCC analysis is not widely use in the design process of construction works. One of the reasons is the lack of a simple model of life cycle costs calculation, which is a tool for supporting investment decisions and indicating the optimal solution already at the design stage. The obligatory application of the methodology contained in [6] will contribute, among others, to the increase of efficiency in using funds being at the investor's disposal.

\section{References}

[1] Grzyl B., Apollo M., Miszewska-Urbańska E., Kristowski A., Zarządzanie eksploatacją obiektu w ujęciu kosztów cyklu życia, Acta Scientiarum Polonorum. Architectura, 2017, 16(2), 85-89

[2] Apollo M., Miszewska-Urbańska E., Analysis of the increase of construction costs in urban regeneration projects, Adv. in Sc. and Tech. - R. J. 9, 2015, 28, 68-74

[3] Dziaduch I., Analiza kosztów okresu istnienia (LCC) obiektu technicznego w aspekcie jego niezawodności, Logistyka, 2011, 2, 139-150

[4] Orłowski Z., Wybrane aspekty właściwości użytkowych budynku w okresie jego eksploatacji, Przegląd Budowlany, 2011, 82, 3643 
[5] Grzyl B., Kristowski A., Jamroz K., Gobis A., Methods of estimating the cost of traffic safety equipment's life cycle, in: MATEC Web of Conferences (Vol. 122, p. 02003). EDP Sciences, 2017

[6] Projekt Rozporządzenia Ministra Infrastruktury i Budownictwa z dn. 10 listopada 2017 r. w sprawie metody kalkulacji kosztów cyklu życia budynków oraz sposobu przedstawiania informacji o tych kosztach.

[7] Márquez A. C., Márquez C. P., Fernández J. F. G., Campos M. L., Díaz V. G. P., Life cycle cost analysis, in: Asset Management, Springer, Dordrecht, 2012, 81-99

[8] Norris G. A., Integrating life cycle cost analysis and LCA. The international journal of life cycle assessment, 2001, 6.2, 118-120

[9] Kembłowski M. W., Grzyl B., Siemaszko A., Game Theory Analysis of Bidding for a Construction Contract, IOP Conference Series: Materials Science and Engineering 245/6, IOP Publishing 2017, http://iopscience.iop.org/article/10.1088/1757899X/245/6/062047/meta

[10] Plebankiewicz E., Zima K., Wieczorek D., Review of methods of determining the life cycle cost of buildings, Creative Construction Conference Proceedings, 2015, 21-24 June, Krakow, 309316

[11] Breidenbach D. P., Life cycle cost analysis, In Aerospace and Electronics Conference, 1989. NAECON 1989, Proceedings of the IEEE 1989 National, 1216-1220

[12] PN-EN 63300-3-3 Zarządzanie niezawodnością część 3-3: Przewodnik zastosowań. Szacowanie kosztu cyklu życia, 2006.

[13] ISO 15686-5:2008 Buildings and constructed assets: Service life planning. Part 5: Life-cycle costing.

[14] Plebankiewicz E., Zima K., Wieczorek D., Life cycle cost modelling of buildings with consideration of the risk, Archives of Civil Engineering, 2016, 62.2, 149-166

[15] Plebankiewicz E., Zima K., Wieczorek D., Quantification of the risk addition in life cycle cost of a building object, Technical Transactions, 2017, 5, 35-45
[16] Grzyl B., Kristowski A., Proces kontroli kosztów w kolejnych fazach inwestycji budowlanej, TTS Technika Transportu Szynowego, 2013, 10, 1663-1668

[17] Kristowski A., Koncepcja modelu procesu eksploatacji obiektów budowlanych. Zeszyty Naukowe Politechniki Gdańskiej, Budownictwo Lądowe 61, 2007, 193-201

[18] Kowalski D., Grzyl B., Kristowski A., The Cost Analysis of Corrosion Protection Solutions for Steel Components in Terms of the Object Life Cycle Cost, Civil and Environmental Engineering Reports, 2017, 26.3, 5-13

[19] Fabrycky W. J., Blanchard B. S., Life-cycle cost and economic analysis, 1991.

[20] Ciambrone D. F., Environmental life cycle analysis. CRC Press, 2018

[21] Frangopol D. M., Liu M., Maintenance and management of civil infrastructure based on condition, safety, optimization, and lifecycle cost. Structure and infrastructure engineering, 2007, 3(1), 29-41

[22] Grzyl B., Miszewska-Urbańska E., Apollo M. The life cycle cost of a building from the point of view of environmental criteria of selecting the most beneficial offer in the area of competitive tendering, E3S Web of Conferences 17/ 00028, 2017.

[23] Grzyl, B., Kristowski, A., Miszewska-Urbańska, E.. Analysis and Risk Evaluation on the Case of Alteration, Revitalization and Conversion of a Historic Building in Gdańsk. In IOP Conference Series: Materials Science and Engineering (245/ 8, p. 082049). IOP Publishing, 2017.

[24] EN 1990:2002 Basis of structural design.

[25] Bulletin of BRB construction works price, Sekocenbud I quarter 2018. 